\title{
The Development of Rainfall Temporal Pattern for Kuantan River Basin
}

\author{
"S.R. Samat, N. Othman and N.F.M. Zaidi \\ Faculty of Civil \& Water Resources, Universiti Malaysia Pahang, Kuantan, Pahang, Malaysia \\ *Email: shairul@ump.edu.my
}

\begin{abstract}
One of the design rainfall event used in flood estimation is rainfall temporal pattern that gives the proportion of total rainfall in different periods within a given duration. The study focuses on developing a temporal rainfall pattern for the Kuantan River Basin in Pahang. According to Urban Stormwater Manual Second Edition (MSMA 2) that used as guideline for designing stormwater in Malaysia, rainfall temporal patterns are divided by region. In this study, the developments of rainfall temporal pattern in Kuantan River Basin are based specifically on rainfall station in this river basin. The Average Variability Method (AVM) that used in MSMA 2 and recommended by the Australian Rainfall and Runoff were used in developing rainfall temporal pattern for this study. The rainfall data of every 5 minutes for 16 years starting from 2000 to 2015 were gathered from Department of Irrigation and Drainage (DID) for purpose of study. In this study, the rainfall temporal pattern is deriving for 15 minutes, 30 minutes, 60 minutes, 120 minutes, 180 minutes and 360 minutes. The results show the significance differences of the rainfall temporal patterns between the results from this study and available value in MSMA 2 for the region of Pahang (Region 2). Therefore, each specific rainfall station has its own reliable rainfall temporal pattern that crucially important for flood estimation in Kuantan River Basin for future development plan.
\end{abstract}

Indexed Terms- - Rainfall Temporal Pattern; Average Variability Method; Kuantan River Basin.

\section{INTRODUCTION}

Rainfall temporal pattern (RTP) is considered to be one of the most critical variables in design flood estimation which show a wide variability from storm to storm i.e. with respect to time and space. Estimated catchment responses to rainfall events are strongly influenced by the temporal variability of rainfall. Accurate representation of the temporal variability of rainfall (i.e., intensity) is critical to correctly predict runoff showed that, even for short storm durations, the temporal variability of rainfall has a significant effect on runoff hydrographs and flood frequency curves. The rainfall temporal pattern gives the proportion of total rainfall in different periods within a given duration (Rahman, A., et.al., 2005).

In Malaysia, rainfall temporal pattern published in Urban Stormwater Manual Second Edition (MSMA2) by Department of Irrigation and Drainage Malaysia that used as guideline for any project related designing stormwater. The rainfall temporal patterns are divided by five (5) region; Region 1: Terengganu, Kelantan and Northern Pahang, Region 2: Johor, Negeri Sembilan, Melaka, Selangor and Pahang, Region 3: Perak, Kedah, Pulau Pinang and Perlis, Region 4: Mountainous Area and Region 5: Urban Area (Kuala Lumpur). In MSMA2, the rainfall temporal patterns were developed for nine standard durations; 15, 30, 60, 180 minutes and 6, 12, 24, 48 and 72 hours.

In MSMA2 also, the published RTP only referred using regions not at stations or at sites (KuantanRegion 2: Johor, NS, Melaka, Selangor \& Pahang). Then, the available data used in MSMA2 length 
up to 2009 (not updated). Based on the Meteorological Department Malaysia (MDM) report in December 2014, the total monthly rainfall in December at these areas achieved more than $1200 \mathrm{~mm}$, which is about $60 \%$ higher than the average monthly rainfall during normal condition. From the report also stated that the highest total rainfall amount was recorded at Kuantan station is $1806 \mathrm{~mm}$. This situation shows there is a significantly need to develop revised rainfall temporal especially for Kuantan River Basin due to climate and rainfall trend changes based on updated rainfall data. Thus, the aim of the current study is to develop RTP based on five (5) stations in Kuantan River Basin with good availability of data and compare the revised RTP with the RTP in MSMA2.

\section{RAINFALL TEMPORAL PATTERN (RTP)}

According to Rahman, A., et.al., in 2005, the main characteristics of design rainfall are a duration, average rainfall intensity of an average recurrence interval (ARI) and also RTP. The RTP gives the proportion of total rainfall in different periods within a given duration.

RTP is important for runoff and flood estimation also effect the water resources and planning. Rainfall analyses are significant for the primary aspect for hydrological designs and RTP provides the general rainfall event to the engineers and designers (Rosmina, A. B., et al., 2012). Presently, there are many established methods such as Average Variability Method (AVM), Huff Time Distributions, Triangular and SCS method used in deriving RTP.

Based on MSMA2 and Hydrological Procedure 1 (HP1), the AVM was used on developing RTP in Malaysia which recommended by Australian Rainfall and Runoff (AR\&R) 1987. The recommended standard durations and interval for design RTP in MSMA2 are shown in Table 1.

Table 1: Recommended Interval for Design RTP in MSMA2

\begin{tabular}{|l|l|}
\hline Storm Duration (minutes) & Time Interval (minutes) \\
\hline Less than 60 & 5 \\
\hline $60-120$ & 10 \\
\hline $121-360$ & 15 \\
\hline Greater than 360 & 30 \\
\hline
\end{tabular}

\section{METHODOLOGY}

Kuantan River Basin (KRB) is in the district of Kuantan at the north eastern end of Pahang State in Peninsular Malaysia. KRB is the third largest basin in Pahang after Pahang River Basin and Rompin River Basin, with an area of approximately 1,652 square $\mathrm{km}$. The Kuantan River is about $99.8 \mathrm{~km}$ length with Kenau River at the upstream and it ends toward the South China Sea at Tg. Lumpur.

The rainfall depths in Malaysia are recorded through Hydrological National Network provided by Department of Irrigation and Drainage Malaysia. The study mainly focuses on five (5) rainfall automatic recording gauge stations in Kuantan River Basin. The data of 5 minutes rainfall for 16 years starting from 2000 until 2015 were collected from Department of Irrigation and Drainage (DID), Malaysia and were analyses to develop the rainfall temporal pattern for KRB. The location of selected rainfall stations is shown in Figure 1. The total event for each station and interval represent in Table 2. 


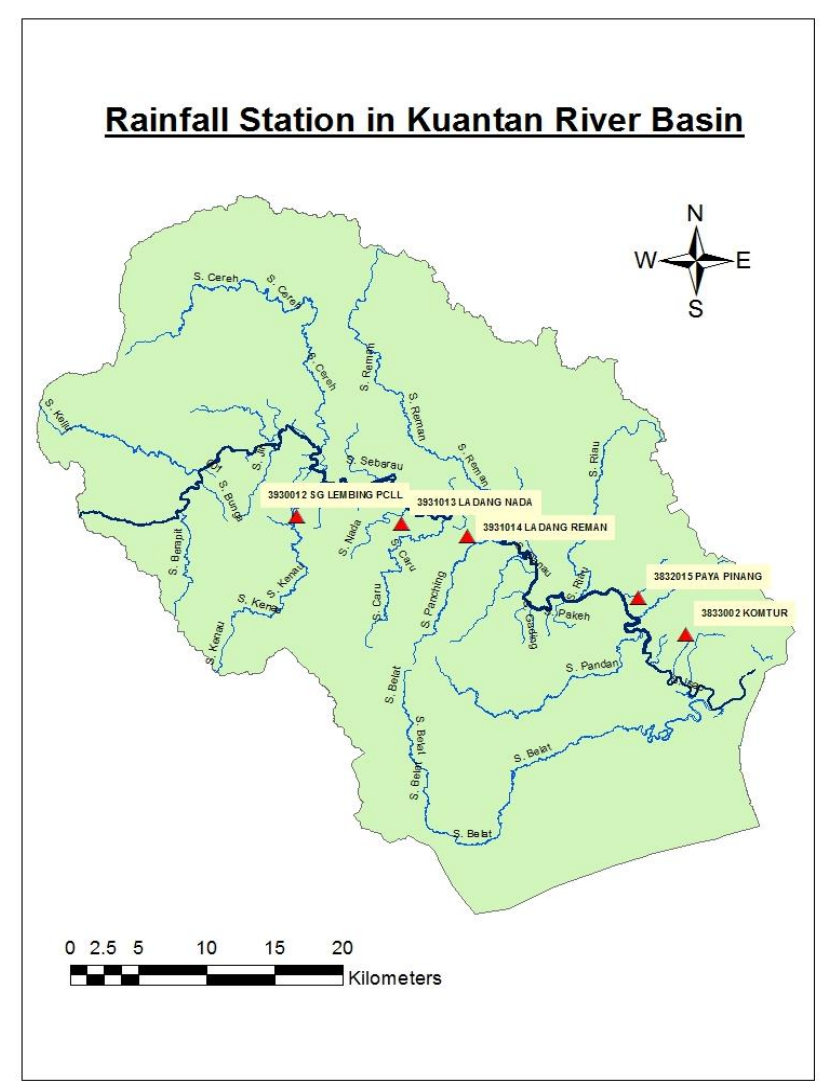

Figure 1: The location of selected rainfall stations in KRB

Table 2: Total Event for Each Station and Interval

\begin{tabular}{|c|c|c|c|c|c|c|c|c|}
\hline \multirow{2}{*}{$\begin{array}{l}\text { Station } \\
\text { ID }\end{array}$} & \multirow[t]{2}{*}{ Station } & \multirow[t]{2}{*}{ Year } & \multicolumn{6}{|c|}{ Duration } \\
\hline & & & $\begin{array}{c}15 \\
\text { min }\end{array}$ & $\begin{array}{c}30 \\
\text { min }\end{array}$ & $\begin{array}{c}60 \\
\text { min }\end{array}$ & $\begin{array}{l}120 \\
\text { min }\end{array}$ & $\begin{array}{l}180 \\
\text { min }\end{array}$ & $\begin{array}{l}360 \\
\min \end{array}$ \\
\hline 3930012 & $\begin{array}{l}\text { Sg. Lembing } \\
\text { P.C.C. L Mill }\end{array}$ & $\begin{array}{c}2000 \\
- \\
2015\end{array}$ & 664 & 311 & 125 & 27 & 13 & 0 \\
\hline 3931013 & Ldg. Nada & $\begin{array}{c}2008 \\
- \\
2015\end{array}$ & 177 & 97 & 63 & 19 & 4 & 2 \\
\hline 3931014 & $\begin{array}{l}\text { Ldg. Kuala } \\
\text { Reman }\end{array}$ & $\begin{array}{c}2008 \\
-2015\end{array}$ & 140 & 76 & 49 & 23 & 2 & 2 \\
\hline 3832015 & $\begin{array}{l}\text { Rancangan } \\
\text { Pam Paya } \\
\text { Pinang }\end{array}$ & $\begin{array}{c}2002 \\
- \\
2015\end{array}$ & 445 & 167 & 58 & 16 & 7 & 0 \\
\hline 3833002 & $\begin{array}{l}\text { Pejabat JPS } \\
\text { Negeri } \\
\text { Pahang }\end{array}$ & $\begin{array}{l}2000 \\
- \\
2015\end{array}$ & 535 & 242 & 106 & 24 & 7 & 1 \\
\hline
\end{tabular}

In Table 2, there are less rainfall events for long durations interval such as 180 minutes and 360 minutes. For 360 minutes duration, only three stations have rainfall events. Only one event for station 3833002, therefore no RTP was developed.

For this study, the rainfall temporal pattern is developed using Average Variability Method (AVM) recommended by AR\&R (1987). Below are the procedures taken in order to develop temporal rainfall 
patterns for Kuantan River Basin by using the Average Variability Method (AVM) proposed in MSMA2:

1. From the data extraction, select and rank 10 most intense rainfalls for each duration selected.

2. Assign a rank for each interval based on rainfall amount.

3. Determine the percentage of rainfall occurred in each interval.

4. Calculate mean for rank and percentage of rainfall for each interval.

5. Assign new rank based on the mean of rank and percentage of rainfall.

6. Convert the percentage rainfall into fraction of total rainfall.

7. Plot Rainfall Temporal Pattern.

8. For comparison purpose, calculate the mean for selected stations.

\section{RESULTS \& DISCUSSIONS}

Development of Rainfall Temporal Pattern

The analysis of ten most intense rainfall for each 15 minutes, 30 minutes, 60 minutes, 120 minutes, 180 minutes and 360 minutes duration for each station based on data from 2000 until 2015 were derived. In this study, the RTP for 120 minutes is also developed even though in MSMA2 there is no duration for 120 minutes. The 120 minutes rainfall duration one of the most frequent happened and suggested as standard durations in Australian Rainfall \& Runoff (AR\&R) Revision Project 3: Temporal Patterns of Rainfall in December 2015.

The derivation of rainfall temporal pattern using the Average Variability Method (AVM) of 15 minutes rainfall duration for Sg. Lembing P.C.C.L Mill rainfall station is shown in Table 3 as mentioned by Nurulain (2016).

Table 3. Analysis for 15 Minutes Rainfall Duration at Sg. Lembing P.C.C.L Mill Rainfall Station

\begin{tabular}{|l|l|l|l|l|l|l|l|l|c|c|}
\hline $\begin{array}{l}\text { Storm Duration = 15 min } \\
\text { Number of Intervals = 3 }\end{array}$ & \multicolumn{2}{l|}{$\begin{array}{l}\text { Rain (mm) at 5 } \\
\text { minute Interval }\end{array}$} & \multicolumn{2}{l}{$\begin{array}{l}\text { Rank of Each } \\
\text { Rainfall Interval } \\
\text { Mean Rank for the } \\
\text { Intervals with Same } \\
\text { Rainfall Values) }\end{array}$} \\
\hline
\end{tabular}


Figure 2 until Figure 6 show the derived RTP for each interval (15, 30, 60, 120 and $180 \mathrm{~min})$ at Sg. Lembing P.C.C.L Mill rainfall station.

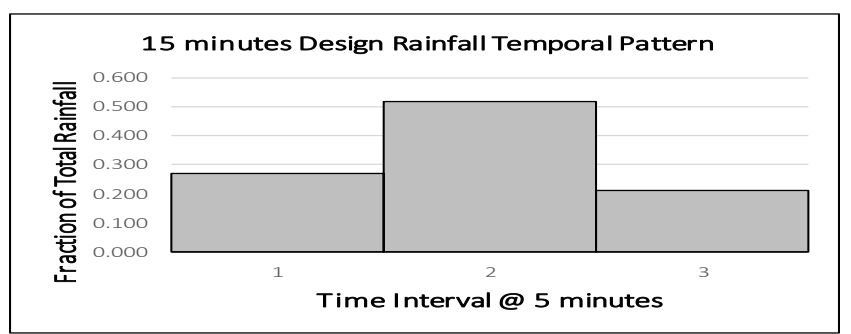

Figure 2: Rainfall Temporal Pattern for 15 Minutes Duration at Sg. Lembing P.C.C.L Mill Rainfall Station

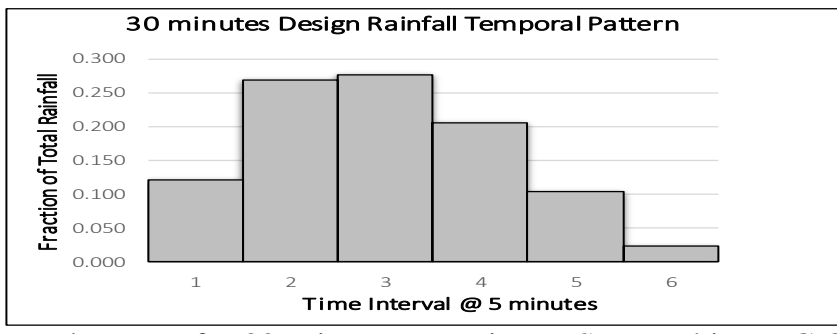

Figure 3: Rainfall Temporal Pattern for 30 Minutes Duration at Sg. Lembing P.C.C.L Mill Rainfall Station

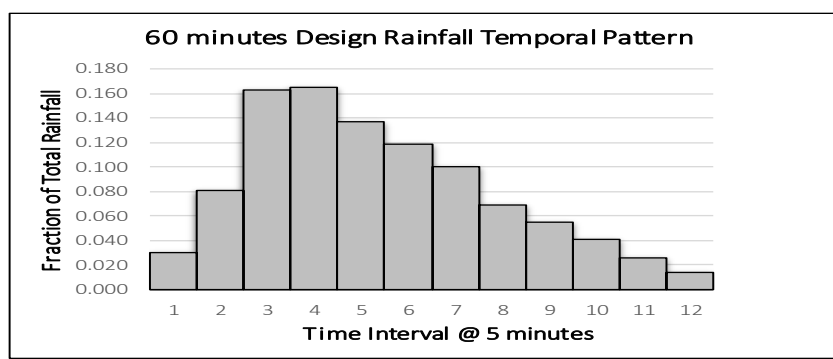

Figure 4: Rainfall Temporal Pattern for 60 Minutes Duration at Sg. Lembing P.C.C.L Mill Rainfall Station

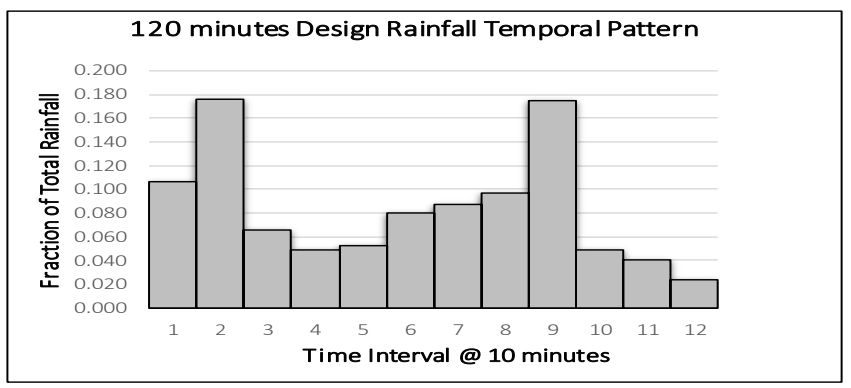

Figure 5: Rainfall Temporal Pattern for 120 Minutes Duration at Sg. Lembing P.C.C.L Mill Rainfall Station

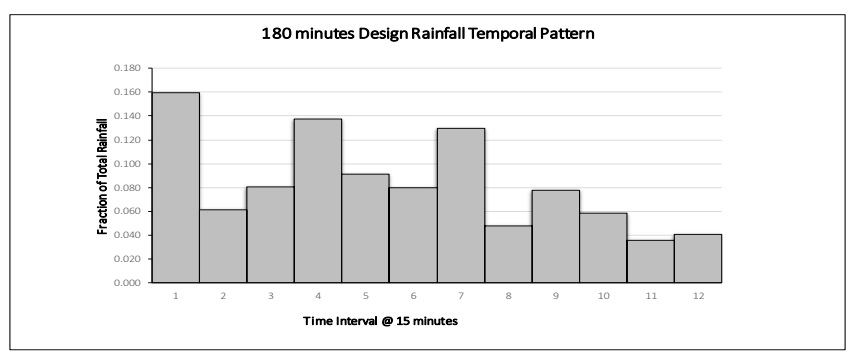

Figure 6: Rainfall Temporal Pattern for 180 Minutes Duration at Sg. Lembing P.C.C.L Mill Rainfall Station 
Normalised Rainfall Temporal Pattern

According to Hydrologic Procedure 1 (2010), the normalization (standardization) of actual storm profile is by generating accurate peak discharge or runoff estimation. The concept of normalization is rearranging the storm pattern so that the greatest value occurs at the middle of the total duration (TP 149, 1973).

Figure 7 until Figure 11 represent the normalized RTP for each interval (15, 30, 60, 120 and 180 min) at Sg. Lembing P.C.C.L Mill rainfall station which is similar in MSMA2.

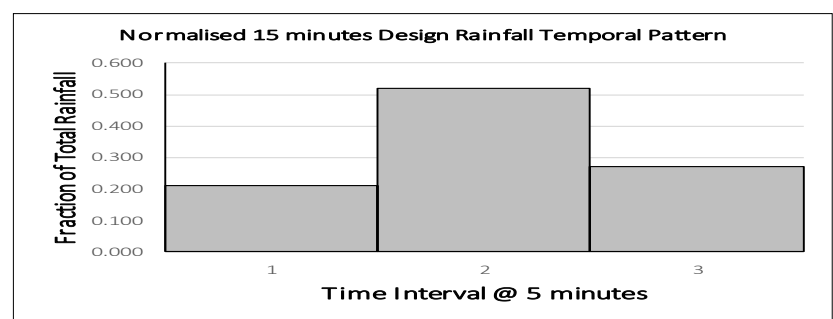

Figure 7. Normalised Rainfall Temporal Pattern for 15 Minutes Duration at Sg. Lembing P.C.C.L Mill Rainfall Station

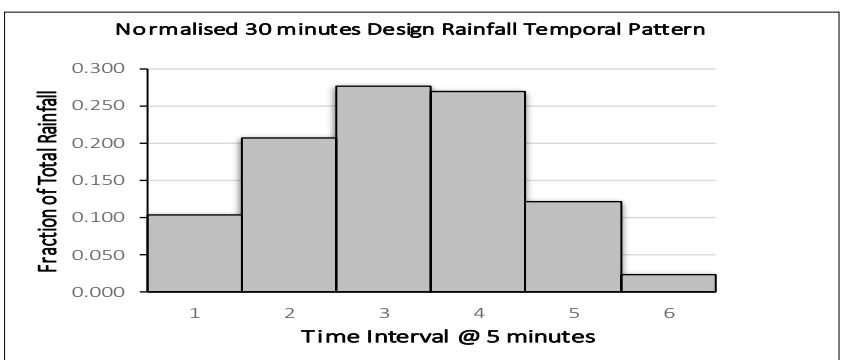

Figure 8. Normalised Rainfall Temporal Pattern for 30 Minutes Duration at Sg. Lembing P.C.C.L Mill Rainfall Station

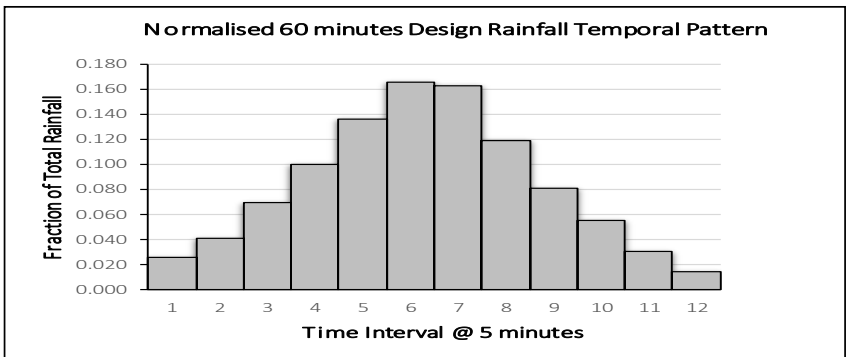

Figure 9. Normalised Rainfall Temporal Pattern for 60 Minutes Duration at Sg. Lembing P.C.C.L Mill Rainfall Station

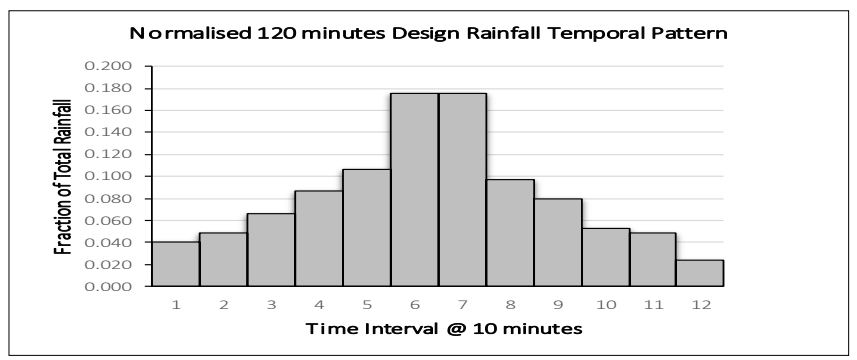

Figure 10. Normalised Rainfall Temporal Pattern for 120 Minutes Duration at Sg. Lembing P.C.C.L Mill Rainfall Station 


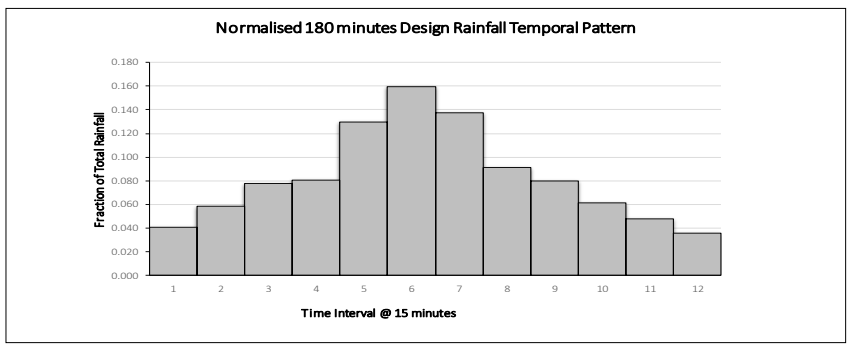

Figure 11. Normalised Rainfall Temporal Pattern for 180 Minutes Duration at Sg. Lembing P.C.C.L Mill

\subsection{Comparison}

\section{Rainfall Station}

Table 4 shows the comparison between RTP Region 2 in MSMA 2 and normalized RTP for Kuantan River Basin. There is no comparison for 120 minutes because no 120 minutes duration in Region 2.

Table 4. Comparison of Normalised RTP between Region 2 (MSMA2) and the revised RTP for Kuantan River Basin

\begin{tabular}{|c|c|c|c|c|c|c|c|c|c|c|c|c|}
\hline $\begin{array}{c}\text { No of } \\
\text { Block }\end{array}$ & \multicolumn{2}{|c|}{15 min } & \multicolumn{2}{|c|}{30 min } & \multicolumn{2}{|c|}{60 min } & \multicolumn{2}{|c|}{120 min } & \multicolumn{2}{|c|}{180 min } & \multicolumn{2}{c|}{360 min } \\
\hline & $\begin{array}{c}\text { Region } \\
2\end{array}$ & KRB & $\begin{array}{c}\text { Region } \\
2\end{array}$ & KRB & $\begin{array}{c}\text { Region } \\
2\end{array}$ & KRB & $\begin{array}{c}\text { Region } \\
2\end{array}$ & KRB & Region 2 & KRB & $\begin{array}{c}\text { Region } \\
2\end{array}$ & KRB \\
\hline 1 & 0.255 & 0.193 & 0.124 & 0.106 & 0.053 & 0.031 & & 0.0336 & 0.053 & 0.042 & 0.044 & 0.028 \\
\hline 2 & 0.376 & 0.528 & 0.130 & 0.185 & 0.059 & 0.052 & & 0.0474 & 0.061 & 0.055 & 0.081 & 0.058 \\
\hline 3 & 0.370 & 0.279 & 0.365 & 0.265 & 0.063 & 0.079 & & 0.0756 & 0.063 & 0.069 & 0.083 & 0.071 \\
\hline 4 & & & 0.152 & 0.243 & 0.087 & 0.099 & & 0.0998 & 0.080 & 0.080 & 0.090 & 0.090 \\
\hline 5 & & & 0.126 & 0.151 & 0.103 & 0.127 & & 0.1132 & 0.128 & 0.114 & 0.106 & 0.124 \\
\hline 6 & & & 0.103 & 0.050 & 0.153 & 0.149 & & 0.1648 & 0.151 & 0.190 & 0.115 & 0.170 \\
\hline 7 & & & & & 0.110 & 0.135 & & 0.1406 & 0.129 & 0.140 & 0.114 & 0.154 \\
\hline 8 & & & & & 0.088 & 0.108 & & 0.1056 & 0.097 & 0.088 & 0.090 & 0.093 \\
\hline 9 & & & & & 0.069 & 0.090 & & 0.093 & 0.079 & 0.071 & 0.085 & 0.082 \\
\hline 10 & & & & & 0.060 & 0.069 & & 0.0594 & 0.062 & 0.061 & 0.081 & 0.066 \\
\hline 11 & & & & & 0.057 & 0.045 & & 0.0432 & 0.054 & 0.044 & 0.074 & 0.041 \\
\hline 12 & & & & & 0.046 & 0.020 & & 0.0242 & 0.042 & 0.033 & 0.037 & 0.025 \\
\hline
\end{tabular}

The results show the RTP for short durations; 15 minutes and 30 minutes had huge percentage of differences which are between $14.5 \%$ to $60 \%$, while for long durations; 180 minutes and 360 minutes, the percentage of between are between $0 \%$ (same value) to $47.8 \%$.

\section{CONCLUSIONS}

From the results, it can be seen that the RTP for short duration; 15 minutes and 30 minutes have quite huge differences. For example, fraction number 4 in 30 minutes duration has $60 \%$ difference between KRB and Region 2. There is no comparison for 120 minutes because no RTP for 120 minutes duration in Region 2 . In overall results, about $53.3 \%$ of fractions have more than $20 \%$ differences between KRB and Region 2 . Hence, this study recommends to use at site RTP in KRB for design purposes that has more reliable values for RTP compare to Region 2 due to massive differences. 


\section{ACKNOWLEDGMENTS}

The authors would like to acknowledge Universiti Malaysia Pahang (UMP) for the funding and support provided towards this project.

\section{REFERENCES}

Department of Irrigation and Drainage Malaysia (2010) Reviewed and Updated the Hydrological Procedure No.1 (Estimation of the Design Rainstorm in Peninsular Malaysia). Department of Irrigation and Drainage Malaysia.

Department of Irrigation and Drainage Malaysia (2012). Urban Stormwater Manual for Malaysia Second Edition. Department of Irrigation and Drainage Malaysia.

Institution of Engineers, Australia (1987). Australian Rainfall \& Runoff (ARER): A Guide to Flood Estimation. Eds Pilgrim, D.H.Barton, ACT.

Institution of Engineers, Australia (2015). Australian Rainfall \& Runoff (ARER) Revision Project 3: Temporal Patterns of Rainfall. Institution of Engineers, Australia.

Meteorological Department Malaysia (2014). Monthly Weather Bulletin. Meteorological Department Malaysia.

Nurulain Fatin, Mahamed Zaidi (2016) The development of rainfall temporal pattern in Kuantan River Basin. Faculty of Civil Engineering and Earth Resources, Universiti Malaysia Pahang.

Rahman, A, S. M., Rahman, K., Khan, S., Shrestha, S. (2005). A Windows-based Program to Derive Design Rainfall Temporal Patterns for Design Flood Estimation. Modeling and Simulation 2005: Modelling and Simulation Society of Australia and New Zealand Inc.

Rosmina A.B., Nor Azalina R., Jethro H.A., Kuan L.P. (2012). Development of Temporal Pattern for Southern Region of Sarawak. UNIMAS E-Journal of Civil Engineering, Vol.3 (Special Issue). UNIMAS.

U.S Department of Agriculture Soil Conservation Service (1973). A Method for Estimating Volume and Rate of Runoff in Small Watersheds. SCS-TP-149; Revised April 1973. 